\title{
Dialectics of a medical provision policy in priority areas in Brazil
}

\author{
César Augusto Trinta Weber ${ }^{1 *}$ \\ ${ }^{1} \mathrm{MD}$, MSc, PhD. Department of Neurosciences and Behavioral Sciences, Faculdade de Medicina de Ribeirão Preto, Universidade de São Paulo, Ribeirão Preto, SP, Brazil
}

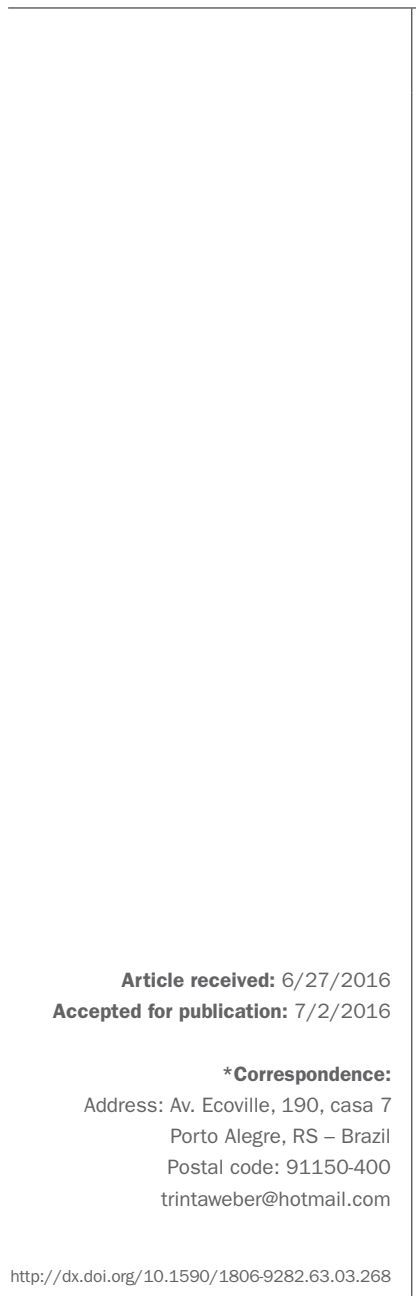

\section{SUMmARY}

Introduction: The people living in vulnerable areas that are difficult to access in Brazil represent a portion of the population that has proven very sensitive to lack of medical and health services. The government, seeking to solve the situation urgently, implemented the More Doctors Program [Programa Mais Médicos, in the Portuguese original] in 2013.

Objective: To discuss the More Doctors Program, with the purpose of contributing to the debate on the provision of medical policies in Brazil.

Method: Study based on the review of official documents: Programa Mais Médicos - dois anos: mais saúde para os brasileiros, 2015 [More Doctors Program - two years: more health for Brazilians, 2015]; Operational Audit Report, TC No 005391/2014-8, the Court of Auditors of Brazil; and Medical Demography in Brazil 2015.

Results: The import of exchange physicians without diploma revalidation has cast a shadow on the technical quality of services offered to the population. In terms of infrastructure, the reduction of resources paralyzed works and made the care network maintenance projects impossible. The creation of new medical schools has created uncertainty about the possibility of quality education being offered, with minimum and sufficient structure including laboratories, clinics and teaching hospitals indispensable to medical training.

Conclusion: The regional inequalities of concentration and dispersion of physicians, showed by studies on medical demography in Brazil, stem from several factors, including the lack of a career path and working conditions. There is no point in having physicians if they do not have safe and ethical conditions to establish the diagnosis and a treatment plan, as well as to monitor the rehabilitation of the patient.

Keywords: primary health care, physicians distribution, public health policy, vulnerable populations, unified health system.

\section{INTRODUCTION}

Brazil's condition of being a continental country, in addition to the historical background of its colonization and its public policies for Development, Infrastructure, Education and Health, ${ }^{1}$ as well as other areas, contributed significantly, especially in the case of the Unified Health System (SUS, in the Portuguese acronym), to the difficulties it has today to guarantee the population's access to health services and actions ${ }^{2}$ in a universal, integral, resolutive and hierarchical way, divided according to levels of complexity and decentralized. These constitute the organizational and philosophical principles of the public health system, which have been regulated by Laws $8.080 / 90^{3}$ and 8.142/90. ${ }^{4}$

From then on, normative and administrative acts of the Ministry of Health began to shape the process of implemen- tation and operationalization of the SUS, particularly regarding its decentralization/municipalization guideline. One of the immediate implications of the decentralization was that the municipalization of health services and actions was, at the time, $1991,{ }^{5}$ for the vast majority of Brazilian municipalities, a major challenge in terms of planning, organization and control of the municipal health system through minimally professionalized management.

In the wake of this, it is worth mentioning some common aspects related to the areas classified as vulnerable and difficult to access, which contribute to understanding the need in these regions. A first aspect is that the Brazilian territory has continental dimensions and a transport system markedly limited by the insufficiency and precariousness of the mobility mesh. Public 
policies, by not favoring the optimum use of the various modalities, miss the focus required for operational efficiency and effectiveness of this system, reinforcing the peripheral condition of these regions. ${ }^{6}$

Another aspect associated with the previous one is that the geographical dimension is an aggravating factor that converges directly to the lack of local and regional basic infrastructure. Cumulatively, this makes the broad and complex sociocultural, environmental and climatic diversity - a characteristic of the great terrestrial extensions - less stimulating and inviting for physicians to live in these places. ${ }^{2}$

In this scenario, the constitutional guarantee of health as a fundamental right ${ }^{7}$ has encountered several barriers for the citizens to be supported by the social medicine developed by the SUS - weakened by insufficient financing $^{1,8}$ and by unprofessional management -, as it does not guarantee quality and resolution for health actions and services. In the words of Gastão Wagner de Souza Campos, governments that, following the populist trend of several municipalities, invented degraded primary care for the poor: Ready Care Units (UPAs), one of the social spaces that we will embarrass ourselves in the future, a sign of human perversity. ${ }^{1}$

Without neglect, it is important to draw attention to the reality of medical demography in Brazil, which reflects the poor distribution of physicians between rural and urban areas, and between capital and the interior. ${ }^{9}$ The concentration and dispersion of physicians in the different regions of the country respond directly to the conditions and the quality of life in these places. Although the concept of quality of life is a subjective construct and therefore does not represent an etymological consensus, it can be considered as the perception individuals have regarding their position in life in the context of the culture and value system in which they live and in relation to their goals, expectations, standards and concerns. ${ }^{10}$

The evolution of the Brazilian health system, with a greater supply of medical jobs and greater demand for health services, coupled with the expansion of medical undergraduation courses, explains the increase in the number of doctors in Brazil over the years. This growth, however, did not benefit the population in a homogeneous way. ${ }^{9}$ The Federal Medical Board points out that although the total number of physicians in certain states is greater on account of the professionals located in the capital, the division between capitals and the interior exposes striking differences. Major cities do attract more professionals. ${ }^{9}$

Populations living in vulnerable and difficult-to-access areas represent a portion of the population that has been very sensitive to the lack of doctors and health services. Epidemiological indicators of these areas show that these are the priority target for interventions within the SUS system, especially in the access and quality of primary care in Brazil. ${ }^{11}$

The Brazilian government, seeking to respond urgently to this situation, implemented the More Doctors Program (PMM, in the Portuguese acronym) by means of Provisional Measure $n^{\circ} 621,{ }^{12}$ published on July 8, 2013, transformed three months later into Law $\mathrm{n}^{\circ} 12.871,{ }^{13}$ aiming at training human resources in the medical field to work within the SUS system, in summary, with the following objectives:

[...] I - To reduce the shortage of doctors in the priority regions [...]; II - Strengthen the provision of basic health care services [...]; III - Improve medical training and provide greater experience in the field of medical practice during the training process; IV - To expand the insertion of physicians in training in the SUS [...]; V - Strengthen the policy of permanent education by integrating teaching and service provision [...]; VI - Promote the exchange of knowledge and experiences between Brazilian health professionals and doctors trained in foreign institutions; VII - Improve medical training for action in public health policies [...]; and VIII - Encourage the development of research applied to the SUS. ${ }^{13}$

With the PMM, the Ministry of Health intends, in general lines, to increase the current number of physicians in Brazil from 374,000 to 600,000 by 2026, reaching the goal of 2.7 medical doctors per 1,000 inhabitants. For that, 11,500 new vacancies will be offered for undergraduate students until 2017, as well as 12,400 new residency positions for the training of specialists, with new courses open in the interior of the country. ${ }^{14}$

The topic of providing and setting up doctors in vulnerable and difficult-to-access areas as a strategy to strengthen the SUS has become a fertile ground for new investigations under the most different approaches. This should be stimulated not only to encourage discussion and technical-scientific production on the subject, but also to serve as a theoretical and technical substrate for monitoring and improving public policies in the SUS.

\section{Method}

Our article, within the limits of an essay, aims to discuss the PMM with the purpose of contributing to the debate on the subject and to join with other academic productions in the field of labor and education management, and the provision of physicians in Brazil as the following studies in their various approaches: Donnangelo; ${ }^{15}$ Don- 
nangelo and Pereira, ${ }^{16}$ who investigated medical labor and the diversification of specializations within hospitals, based on the Social Sciences approach; Gonçalves, ${ }^{17}$ who discussed the process of labor based on a Marxist perspective of the production process; Merhy ${ }^{18}$ who analyzed the micropolitics of labor as a living act in health; Campos, ${ }^{19}$ who criticized the hegemonic management approach and taylorism; Carvalho and Sousa, ${ }^{20}$ who analyzed how Brazil has sought to face a chronic problem in the SUS, which is the lack of physicians in work in public health services, especially in Primary Health Care, as well as other articles and researchers.

For the intellectual exercise described in this manuscript, the concept of problematization is being used based on the teachings of Foucault for whom:

[...] Problematization does not mean representation of a preexisting object, nor the creation by discourse of an object that does not exist. It is the set of discursive or nondiscursive practices that makes something enter the game of the true and the false and constitutes it as an object for thought (whether in the form of moral reflection, scientific knowledge, political analysis, etc.) ${ }^{21}$

According to the Ministry of Health, the three operational dimensions of the PMM are the structuring axes of this policy. For the federal power the Law of the PMM, as a whole, shows, in summary, that:

[...] The first axis would be the Emergency Provision, called "Project More Doctors for Brazil," which aims to promote Primary Care in priority regions of the SUS system [...]. The second axis is that of Investment in Infrastructure of the Network of Basic Health Services [...] Requalification Program for Basic Health Units [...] Computerization of Basic Health Units [...]. The third axis is related to Medical Training in Brazil. [...] creation of medical courses, public and private, [...] creation of the National Register of Specialists [...] and measures for the qualification of medical training both in the scope of undergraduate programs and medical residency. ${ }^{14}$

In this perspective, these operational dimensions/structuring axes of the PMM were analyzed based on official documents from the Ministry of Health (Programa Mais Médicos - dois anos: mais saúde para os brasileiros, 2015 [More Doctors Program - two years: more health for Brazilians, 2015]): ${ }^{14}$ Court of Auditors of Brazil ${ }^{\mathrm{a}}$ (Operational Audit Report TC $\mathrm{n}^{\circ}$

a We chose to use the documentation of the Court of Auditors of Brazil as representative of the users because this Court is an
005.391/2014-8 $)^{22}$ and University of São Paulo's Medical School (FMUSP), the Regional Medical Board of São Paulo and the Federal Medical Board (Demografia Médica no Brasil 2015 [Medical Demography in Brazil 2015]). ${ }^{9}$ All of these publications were selected by identification and recognition - as a technical and legal corpus - representing the players of the health sector, respectively, the public administration, users and sector entities.

\section{Results AND DISCUSSION}

\section{Project More Doctors for Brazil (PMMPB)}

The Brazilian government, pressured to respond to the population's obstacles to access to health services and actions by the SUS, implemented the Project More Doctors for Brazil ${ }^{13}$ (PMMPB), in the context of other measures such as the previous Primary Care Professional Appreciation Program ${ }^{23}$ (PROVAB), created in 2011, which aimed at repressing a growing wave of dissatisfaction and vertiginous drop in government popularity.

The PROVAB was created by a joint initiative of the Ministry of Health and the Ministry of Education, with the purpose of stimulating and valuing the health professional who works in multiprofessional teams in the scope of Primary Care and Family Health Strategy. ${ }^{23}$ In other words, to expand access to health for the poor, encouraging newly trained health professionals to work in regions marked by the scarcity of physicians (periphery of large cities, riverine populations, quilombolas, indigenous peoples, remote areas of the legal Amazon, and the northeastern semi-arid region). ${ }^{20}$

As a stimulus to joining this program, newly trained professionals, in particular physicians, besides improving their professional training and getting to know the reality of SUS users, earn the right to an additional $10 \%$ in medical residency tests. ${ }^{20,23}$ This became a decisive factor for access to specialization, making the PROVAB a stepping stone between undergraduate and graduate programs. ${ }^{23}$ As a possibility to keep physicians in priority areas for more than a year, as originally planned, vacancies for PROVAB were incorporated into the PMMPB.

The inefficiency of the SUS care network is widely known. The slowness of its solutions has led people to suffering and preventable sequelae, if not death. This scenario left no alternative, in the short term, to the Ministry

auxiliary body of the legislative power, which in a representative democracy must translate the wishes of the people. Therefore, the Court is, by secondary and indirect extension, representative of the primary public interests, that is, representative of the interests of the population. 
of Health, but to provide priority areas with physicians for primary health care to these populations.

The PMMPB caused a great reaction of medical entities, due to several aspects. A first aspect that deserves to be highlighted is the creation of the figure of the exchange doctor as a possibility for medical care in areas classified as priorities by the Ministry of Health. ${ }^{24,25}$ The exchange doctor is one who, according to the norm that instituted it, graduated in foreign higher education institutions through international medical exchange. ${ }^{13}$

However, the fact that the Brazilian Government did not require the revalidation of the diploma (Revalida) of the exchange physicians was strongly contested based on the argument that without the proper proof by Brazilian universities of the minimum knowledge required in Brazil for medical practice, the health of the population assisted by such professionals could be put at risk. This is a requirement in many countries to prove technical capacity for professional practice, further thickening the first controversy of the project by its non-compliance or permissiveness, if so preferred. According to the PMMPB:

[...] The participation of the exchange physician in the Project More Doctors for Brazil, attested by the coordination of the Project, is a necessary and sufficient condition for the practice of Medicine in the scope of said project, and article 17 of Law 3.268, dated September 30, 1957, is not applicable. ${ }^{13}$

Another aspect criticized by medical associations is language. Proficiency in the Portuguese language is necessary for proper communication between doctor and patient that ensures full understanding between the interlocutors. Although most of the exchange doctors come from countries where Spanish is the language spoken and written, one should not ignore that the Portuguese spoken in Brazil has specificities that can be decisive for the success or failure of a health intervention. There are too many risks of poor communication.

A third aspect to be mentioned is Brazil's agreement with the Pan American Health Organization (PAHO), which provides for the arrival of 4,000 Cuban doctors to work as exchange physicians, with an investment of R 511 million.

The initiative to bring Cuban doctors through PAHO may have been one of the measures that causing most controversy and outrage since the announcement and implementation of the project. The amount of $\mathrm{R} \$ 10,000.00$ paid as a scholarship by the federal government to the exchange doctors proved to be much higher than the amounts paid, for example, for medical training in the country by the medical residency services funded by the Ministry of Education and Culture or the average salaries paid by local administrations for Brazilian doctors working in primary care.

This fact alone would by itself displease the Brazilian medical community, as it lacks a convincing explanation from the federal government to justify this wage policy. On top of this, the warning made of the risk that there might be the dismissal of Brazilian doctors hired in the municipalities that received exchange physicians ended up being confirmed, a fact that contributed to generate even more problems.

By bringing in exchange doctors without the labor guarantees in force in the country, the Brazilian government has turned its back on the historic achievements of workers who sought to establish and guarantee an ethical relationship between capital and labor. As an aggravating circumstance, the fact that the exchange physicians receive only the equivalent of $20 \%$ of the value paid by the grant, around US\$ 600 , and the remaining $80 \%$ is passed on to the Government of Cuba as compensation for the cost of academic training of these professionals, casts a shadow on the project's objectives.

In this dialectical game, we cannot lose sight of the thesis defended by medical institutions that the poor distribution of physicians in Brazil is a consequence, among other things, of the lack of infrastructure and health equipment in areas other than capitals and of a national career plan with positions and salaries for physicians in the SUS (PCCV/SUS, in the Portuguese acronym). It should be noted that the complaint is prior to the implementation of the PMM. In the view of medical entities, this would be the most prudent and effective governmental measure to solve the problem.

The creation of the PCCV/SUS would lead doctors to the areas that are vulnerable and difficult to access, or even those farther away from the large urban centers, since the legal condition for filling the position of a medical doctor in the SUS to work in a certain location would be the classification obtained by the candidate after public competition, according to vacancies previously known and not yet filled. With proper normative support for career progression and rise in functions, the PCCV/SUS would allow physicians within the SUS security and encouragement to move, after a certain number of years of work and performance assessment, to cities that are knowingly more developed, as seen in the cases of Justice Courts, the Federal Prosecution Service and the Federal Police, as well as other public office careers. 
Figure $1^{9}$ shows the distribution of physicians per Brazilian region in 2014 . In order to better illustrate the medical distribution presented here, the following aspects should be highlighted, among other characteristics of the medical population in the country: a) number of registered doctors: 419,224; b) Brazilian population: 201,032,714 inhabitants; c) ratio physician per 1,000 inhabitants: 2.09.

It is important to show some of the main results of the evaluations made by the Ministry of Health to assess the two years of implementation of the $\mathrm{PMMPB}^{8}$ and the audit conducted by the Court of Auditors of Brazil ${ }^{22}$ in the Ministries of Education and Health; in the government of the Federal District; and in local administrations in the states of Bahia, Minas Gerais, Pernambuco, São Paulo, Ceará, Maranhão, Pará and Rio Grande do Norte.

For the Ministry of Health, the results achieved by the program, as well as its approval by the population that uses the SUS, already demonstrate the success of this broad and innovative initiative. This would be enough to prove that the most immediate dimension of the project - that of emergency provision of professionals - has been successfully achieved.

[...] Currently, the PMM offers a total of 18,240 positions in 4,058 municipalities across the country, covering $73 \%$ of Brazilian cities and 34 Indigenous Special Sanitary Districts (DSEIs). In just two years, all the demand from the local administrations that adhered to the Program has been met, and with this, 63 million Brazilian citizens are already benefiting from the presence of physicians in 4,058 municipalities throughout the country. The Ministry of Health estimates that, by the end of 2018, 70 million Brazilians will be cared for by the More Doctors Program. ${ }^{14}$

The Court of Auditors of Brazil in an operational audit ${ }^{22}$ performed in the PMM focused on the period between

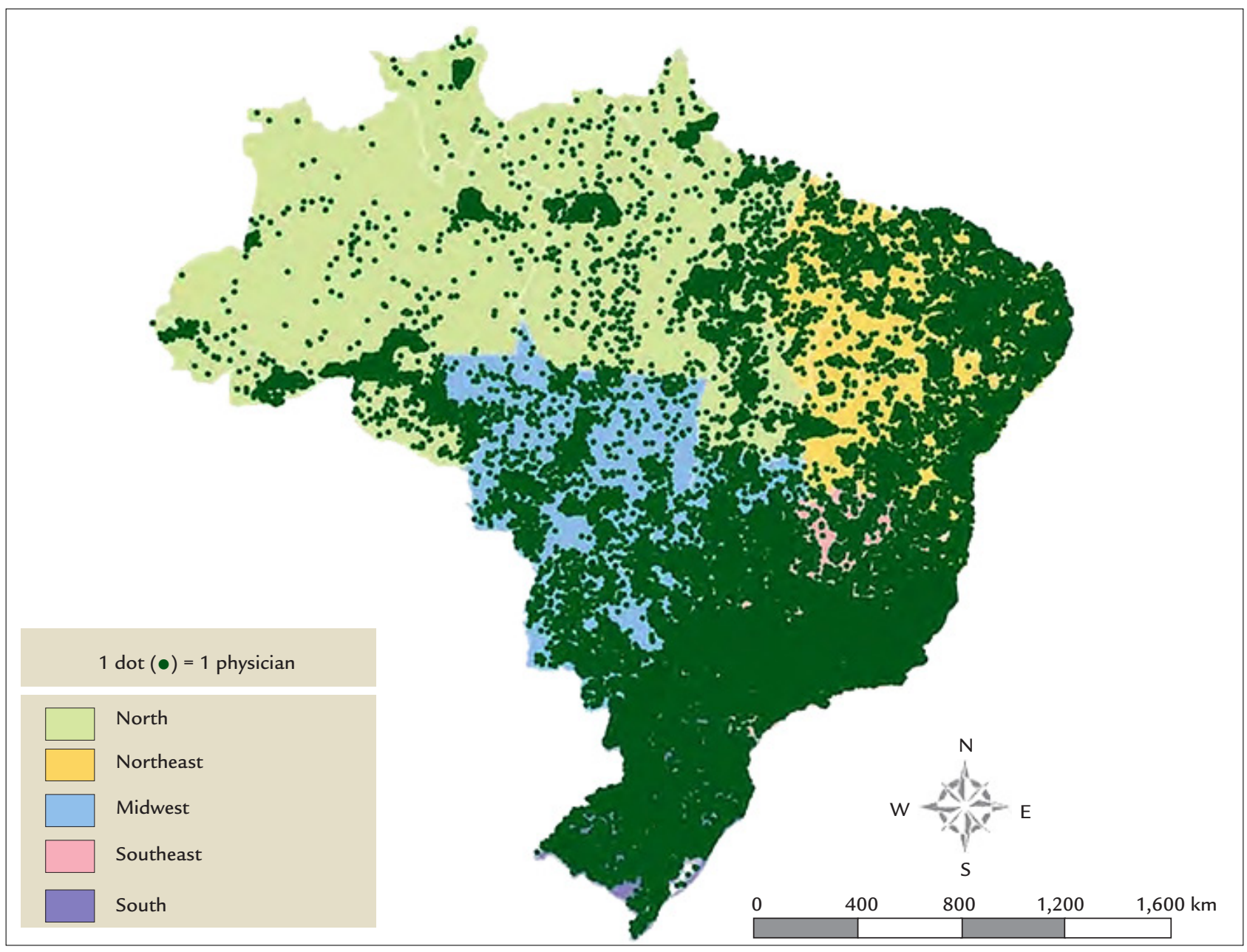

FIGURE 1 Distribution of physicians according to region in Brazil, 2014.

Source: Scheffer et al. ${ }^{9}$ 
June 2013 and March 2014 detected, among other errors, the fragility of supervision and mentoring of doctors in the PMMPB. The risk of absence of supervising physicians or disregard of the ratio of exchange physicians per supervisor was strongly pointed out by the Federal Board of Medicine and the 27 Regional Boards due to its potential of endangering the health of the population:

[...] By act or omission, characterized by malpractice, recklessness or negligence; - indication of procedure, even with the participation of several physicians, that results in damage; - the non-use in the patient's favor of all available means of diagnosis and treatment, scientifically recognized and within reach; - or the cover-up of unethical conduct in disfavor of the patient. ${ }^{22}$

According to the Court of Auditors of Brazil, exchange physicians in the PMMPB as foreseen by Law $\mathrm{n}^{\circ}$ $12871 / 2013$ were able to participate in the program even without their diplomas being revalidated, under the condition of having their work supervised. Thus, when supervision does not occur, even if envisaged by law, and revalidation of the diploma is not done, this could, in fact, be a typical case of illegal medical practice. ${ }^{22}$

As for mentoring, it was found that the insufficient number of mentors would lead to the accumulation of physicians by mentor, a fact that contributes to the precariousness of the mentoring with damages to the academic guidance and even, in some places, the absence of monitoring for several physicians who are in the project. ${ }^{22}$

Another finding of the audit by the Court of Auditors of Brazil concerns the inconsistencies found in the Reception Module ${ }^{26,27}$ which allowed for the approval and effective performance of physicians who did not meet the minimum performance adequacy criteria set forth in Joint Ordinance $\mathrm{n}^{\circ} 1 / 2014 .{ }^{26}$ According to the norm, this module would include content related to the legislation governing the Brazilian health system, the functioning and attributions of the SUS system, notably regarding Primary Health Care, the clinical protocols for care defined by the Ministry of Health, the Portuguese language and the code of medical ethics.

The seriousness of the inconsistencies registered by the auditing authority largely reinforces the reasons for the public's disbelief in the PMM as a whole and the risks arising from its implementation, especially in the absence of a guarantee of technical quality of the professional services rendered. It should be noted that a number of exchange physicians did not demonstrate sufficient knowledge to practice medicine or did not prove the com- mand of the language, in addition to being exempted from revalidating the diploma in the country. ${ }^{22}$

A final note from the Court of Auditors of Brazil to be mentioned in this section, due to the limitations agreed for the size of this manuscript, deals with the existence of failures in the distribution of physicians of the PMMPB, that is, the lack of care in municipalities in need or with difficulty to maintain physicians of the Family Health Teams. For the Court of Auditors of Brazil, some situations could justify the finding that:

[...] the way the selection process of the participating municipalities occurs can be pointed out as one of the causes for this poor distribution of the physicians in the project. The fact that it is necessary for the municipality to express its interest and indicates the vacancies existing for doctors could lead to a large number of doctors directed to municipalities with better planning and articulation capacity to the detriment of smaller, needy municipalities. The lack of prioritization by the Ministry of Health of municipalities with the greatest shortage of physicians and that are located in areas which are difficult to access and provide for this professional. ${ }^{22}$

\section{Infrastructure}

In 2001, the Ministry of Health created the Program for the Rehabilitation of Basic Health Units (Requalifica UBS), having almost tripled its budget in 2013, the year of the launch of the More Doctors Program, when it became one of the axes of the program, benefiting 4,949 municipalities throughout Brazil.

Table 1 shows the status of development and completion of the infrastructure works financed by the program, in June 2015.

According to the Ministry of Health, the improvement of the infrastructure of Primary Care in Brazil has been due to the construction of new basic health units and the

\begin{tabular}{|c|c|c|c|c|c|c|c|}
\hline \multirow[t]{2}{*}{$\begin{array}{l}\text { Type of } \\
\text { works }\end{array}$} & \multicolumn{2}{|c|}{$\begin{array}{l}\text { Not } \\
\text { initiated }\end{array}$} & \multicolumn{2}{|c|}{ In progress } & \multicolumn{2}{|c|}{ Finished } & \multirow{2}{*}{$\begin{array}{l}\text { Total } \\
\mathrm{N}\end{array}$} \\
\hline & $\mathbf{N}$ & $\%$ & $\mathbf{N}$ & $\%$ & $\mathbf{N}$ & $\%$ & \\
\hline Construction & 618 & 7.8 & 5,703 & 72.2 & 1,577 & 20.0 & 7,898 \\
\hline Expansion & 508 & 6.8 & 3,003 & 40.1 & 3,984 & 53.2 & 7,495 \\
\hline Renovation & 498 & 6.4 & 2,281 & 29.2 & 5,027 & 64.4 & 7,806 \\
\hline Boat-based & 28 & 62.2 & 15 & 33.3 & 2 & 4.4 & 45 \\
\hline \multicolumn{8}{|l|}{ UBS } \\
\hline Total & 1,652 & 7.1 & 11,002 & 47.3 & 10,509 & 45.6 & 23,163 \\
\hline
\end{tabular}

Source: Department of Primary Care/SAS/MS apud Ministério da Saúde/SGTES. ${ }^{14}$ 
renovation and expansion of existing units. These are investments of more than R $\$ 5$ billion to finance 26,000 works in almost 5,000 municipalities, of which approximately 10,500 are ready and other 10,000 are in progress. ${ }^{8}$ All these efforts are being made in order to ensure the necessary structure for SUS physicians to care for the population with the highest quality and motivation.

Almost two-thirds (65\%) of the total of 10,987 construction, expansion and renovation works of UBS that are in progress have more than $50 \%$ of the project carried out [...]. Preliminary results of researches still in progress have shown that the new UBS centers offer a greater diversity of services to the users, that is, present a wider range of practices. This meets the objective of solving more problems in the UBS by expanding not only the quantity of the same actions, but also performing actions that, before, the user had to look for another service to perform [...]. ${ }^{14}$

Although the results presented by the Ministry of Health may appear to be welcome, the history of budget cuts and the contingency of resources that impede investments, paralyze works and make projects for maintenance, recovery and expansion of health services and actions impossible reinforce and justify the feeling of dissatisfaction with the success of the measures already announced and others that will follow.

The picture of the SUS health care network leaves no doubt as to its fragility due to insufficient equipment and inputs for the promotion, prevention, care and rehabilitation of health, as well as the poor equipment and the limited human resources indispensable for full functioning. A recent example of the policy of expansion and for qualification of the assistance network is the construction of UPAs, which is disastrous both for the unfinished works and for those that have been closed due to lack of personnel, equipment and supplies. ${ }^{1}$

Medical training in Brazil, medical courses and medical residency The Ministry of Health feels it is through this axis that it will be possible to solve, permanently, the problem of the lack of professionals. Thus, the program includes an expansion plan for undergraduate and medical residency courses and important changes in the way doctors and specialists are trained. The goal of the Federal Government is to create 11.5 thousand new vacancies in undergraduate courses and 12.4 thousand positions for medical residency until 2017. Of these, over 5,000 undergraduate vacancies have already been authorized and nearly 5,000 for residency.
[...] Plan and regulate the expansion of medical education in Brazil [...]. New National Curriculum Guidelines for Medical Courses. [...] Implementation of the progressive evaluation for medical students of the second, fourth and sixth years provided for in Law no. 12871/2013. [...] Implementation of the Organizational Contracts for Public Action of Health Teaching [...] Caring for SUS users by physicians who have already been awarded their undergraduate degree and who will be doing their specialization in General Family and Community Medicine. [...] Guarantee of universalization of access to medical residency for all medical graduates who finished their undergraduate programs in the previous year up to 2018. [...] Training of one or two years for all physicians who want to follow another specialty other than the nine mentioned in Law no. 12871/2013. [...] National Register of Specialists in the second half of 2018, with the orientation and planning of the offer of medical residency directed as needed [...]. In the international context, the PMM proposes the institutionalization of a new cycle of reforms in the scope of Brazilian medical education, integrating these processes with the policies of permanent education established in the context of the SUS. ${ }^{14}$

For medical entities, the creation of new medical schools is unnecessary if one takes into account that Brazil is the second country in the world with the largest number of medical schools, behind India, only. If we use the population criterion, Brazil comes first - India has 1.2 billion inhabitants and 272 schools, Brazil has 190 million people and 175 medical schools. China has 150 schools and 1.35 billion inhabitants. Brazil leaves even the US behind, with its 130 medical schools for approximately 300 million people. ${ }^{28}$

Chart $1^{9}$ shows the increase in the number of medical doctors registered in the Regional Boards of Medicine between 2000 and 2014, and the projections of new vacancies in medical undergraduation courses, according to the forecasts of the Ministry of Education, between 2015 and 2020.

The creation of new medical schools rose doubts and uncertainties about the possibility of quality education being offered as well as minimum and sufficient structure for medical students including laboratories, outpatient clinics and teaching hospitals for service training indispensable to the physician. For the Federal Board of Medicine, most of these new projects do not meet current needs, curriculum guidelines, and minimum conditions for physician training. This will result in poorly trained doctors, which compromises the quality of care. ${ }^{28}$

We cannot fall into the trap that means to reduce or even confuse the figure of the university professor, who 


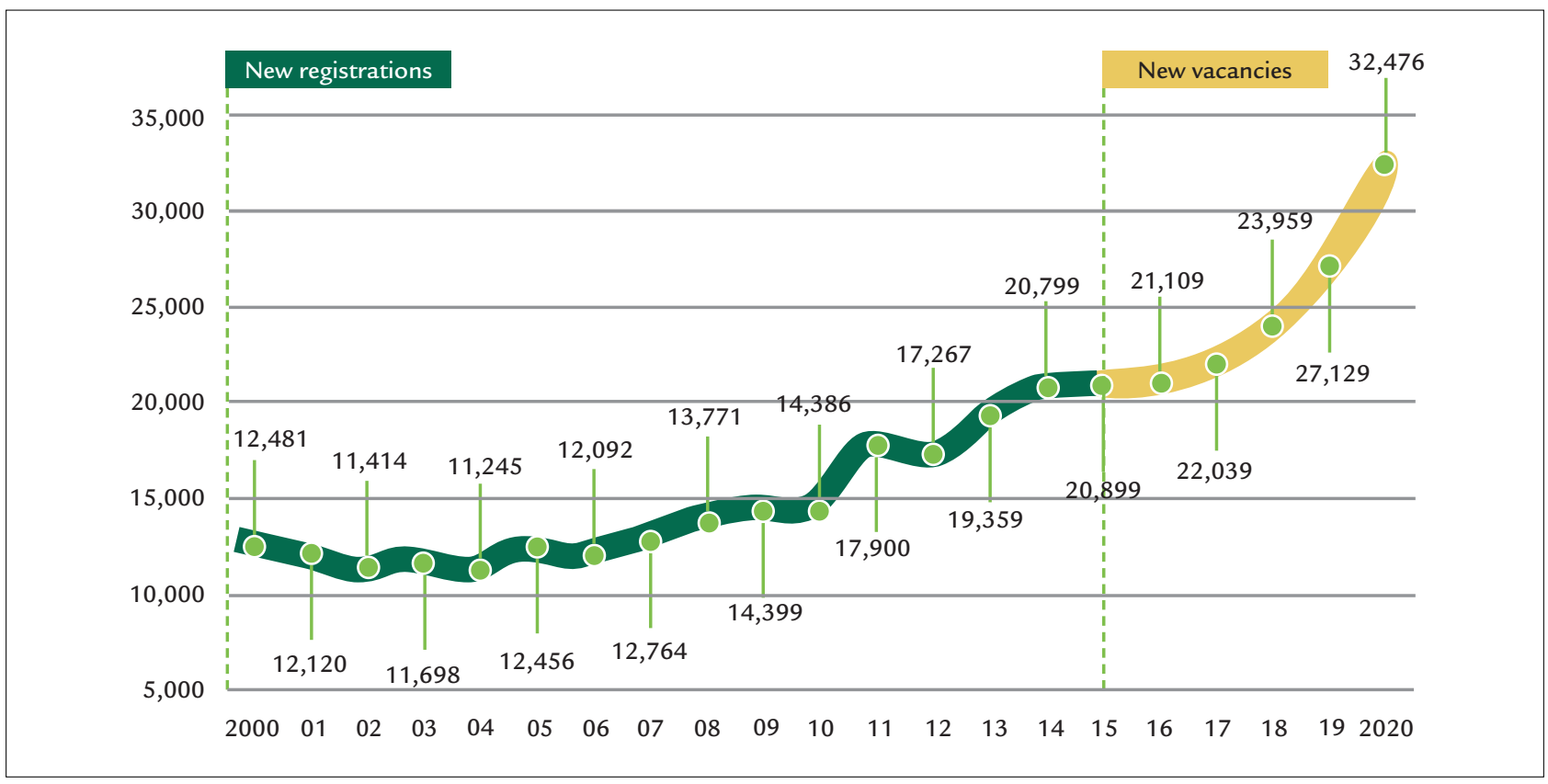

CHART 1 Increase in the number of new physicians, based on new registrations and projection of new vacancies in medical undergraduate

programs - Brazil, 2015.

Source: Scheffer et al. ${ }^{9}$

has stricto sensu training, with that of a medical doctor recognized in the field for his or her professional skills. The latter in relation to the former is not synonymous with ability, talent or vocation to the teaching profession, and is no guarantee of pedagogical technique.

The practice of medicine in Brazil evokes a mosaic, which makes it even more complex to find answers about the ideal profile and number of physicians to respond to the demands and health needs of the population. The significant increase in the number of doctors in the last decades, with more and more professionals entering the labor market each year - which might become more evident with the opening of more medical courses - has not yet been accompanied by spontaneous improvement in the distribution of doctors or a reduction of inequalities in terms of the population's access to medical care. The continued existence of medical "deserts" is paradoxical in a country that strongly invests to increase the number of practicing doctors, without repercussions so far in terms of improving the distribution of such professionals. ${ }^{9}$

\section{Final REMARKS}

The regional inequalities of concentration and dispersion of physicians, demonstrated by studies on medical demography in Brazil, are due to several factors, including the lack of a career plan and working conditions. To improve health in the country, the SUS system needs much more than physicians. The figure of a physician is pointless if there are no safe and ethical conditions to reach a diagnosis, to establish the therapeutic plan and monitor the rehabilitation of the patient. The citizens will continue to be left abandoned by the State, robbed from their right to health, if there is no adequate number of consultations in primary and specialized care units, medicines, laboratory and imaging exams, emergency care and hospital beds.

Local government funding has ended. Both state and federal governments need to invest more. Professional management tends to reduce the inefficiency of the actions and services provided, in addition to hindering the historically capillary corruption in the public machine.

The lack of sufficient studies, whose results can ensure the effectiveness of the PMM, notably by improving health indicators of the population and by assessing SUS user satisfaction, should serve as fuel for deepening the debate and to make future investigations more accurate in every sense.

Therefore, it is not a question of ignoring the merits and advances deriving from the PMM, but rather of seeking to contribute to the absolutely unfinished debate by drawing attention to the possibility of being able to think of it as an object of thought in political analysis to understand it as a biopolitical device for population control. ${ }^{29,30}$ 


\section{Resumo}

Dialética de uma política de provimento médico em áreas prioritárias no Brasil

Introdução: As populações que vivem em áreas vulneráveis e de difícil acesso no Brasil representam uma parcela da população que vem se mostrando bastante sensível à falta de médicos e de serviços de saúde. O governo, buscando responder em caráter emergencial a essa situação, instituiu o Programa Mais Médicos, em 2013.

Objetivo: Problematizar o Programa Mais Médicos, com o propósito de contribuir para o debate sobre as políticas de provimento médico no Brasil.

Método: Ensaio a partir da revisão dos documentos oficiais: Programa Mais Médicos - dois anos: mais saúde para os brasileiros, 2015; Relatório de Auditoria Operacional TC n ${ }^{\circ}$ 005.391/2014-8, do Tribunal de Contas da União, e Demografia Médica no Brasil 2015.

Resultados: A importação de médicos intercambistas, que não passaram por revalidação do diploma, deixou dúvidas sobre a qualidade técnica dos serviços ofertados à população. Na infraestrutura, o contingenciamento de recursos paralisou obras e inviabilizou projetos de manutenção da rede assistencial. A criação de novas faculdades de medicina gerou incertezas quanto à possibilidade de ser oferecido um ensino de qualidade, com estrutura mínima e suficiente de laboratórios, ambulatórios e hospitais-escola, indispensáveis à formação do médico.

Conclusão: As desigualdades regionais de concentração e dispersão de médicos, mostradas por estudos sobre a demografia médica no Brasil, decorrem de vários fatores, como falta de um plano de carreira e de condições de trabalho. De nada adianta ter o médico se este não dispuser de condições seguras e éticas para elaborar o diagnóstico, a terapêutica e acompanhar a reabilitação de seu paciente.

Palavras-chave: atenção primária à saúde, distribuição de médicos, política pública de saúde, populações vulneráveis, sistema único de saúde.

\section{References}

1. Campos GWS. Desafios políticos e organizacionais do SUS: vinte anos de política pública. Cad Saúde Pública. 2008; 24(10):2200-1.

2. Koga D. Territórios de vivência em um país continental. Serv Soc Saúde. 2015; 14(1):9-26.
3. Lei n. 8.080, de 19 de setembro de 1990. Dispõe sobre as condições para a promoção, proteção e recuperação da saúde, a organização e o funcionamento dos serviços correspondentes e dá outras providências. Diário Oficial da União, 19 Sep 1990.

4. Lei n. 8.142, de 28 de dezembro de 1990. Dispõe sobre a participação da comunidade na gestão do Sistema Único de Saúde e sobre as transferências intergovernamentais de recursos financeiros na área da saúde e dá outras providências. Brasília: Diário Oficial da União; 28 Dec 1990.

5. Instituto Nacional de Assistência Médica da Previdência Social. Resolução n. 273, 7 de janeiro de 1991. Brasília; 1991.

6. Barat J. Logística, transporte e desenvolvimento econômico. São Paulo: CLA Editora; 2007. v. 4.

7. Brasil. Constituição (1988). Constituição da República Federativa do Brasil. Brasília: Senado Federal; 1988.

8. Campos GWS. Reforma política e sanitária: a sustentabilidade do SUS em questão? Ciênc Saúde Coletiva. 2007; 12(2):301-6.

9. Scheffer M, coordinator. Demografia Médica no Brasil 2015. São Paulo: Departamento de Medicina Preventiva, Faculdade de Medicina da USP Conselho Regional de Medicina do Estado de São Paulo. Conselho Federal de Medicina; 2015. Available from: http://www.flip3d.com.br/web/temp_ site/edicao-c6a01432c8138d46ba39957a8250e027.pdf.

10. Fleck MPA. O instrumento de avaliação de qualidade de vida da Organização Mundial da Saúde (WHOQOL-100): características e perspectivas. Ciênc Saúde Coletiva. 2000; 5(1):33-8.

11. Oliveira Neto JCDC, Pires MCDC. Indicador municipal de saúde: Uma análise dos Sistemas Municipais de Saúde no Brasil. Planej Políticas Públicas. 2006; (29):79-99.

12. Brasil. Medida Provisória n. 621, de 8 de julho de 2013. Institui o Programa Mais Médicos. Brasília: Diário Oficial da União; 8 Jul 2013.

13. Lei n. 12.871, de 22 de outubro de 2013. Institui o Programa Mais Médicos, altera as Leis n. 8.745, de 9 de dezembro de 1993, e n. 6.932, de 7 de julho de 1981, e dá outras providências. Brasília: Diário Oficial da União; 22 Oct 2013.

14. Ministério da Saúde. Secretaria de Gestão do Trabalho e da Educação na Saúde. Programa mais médicos - dois anos: mais saúde para os brasileiros. Brasília; 2015

15. Donnangelo MCF. Medicina e sociedade: o médico e seu mercado de trabalho. São Paulo: Pioneira; 1975.

16. Donnangelo MCF, Pereira L. Saúde e sociedade. 2. ed. São Paulo: Duas Cidades; 1979.

17. Gonçalves RBM. Práticas de saúde: processos de trabalho e necessidades São Paulo: Cadernos Cefor, Secretaria Municipal de Saúde de São Paulo; 1992.

18. Merhy EE. Um ensaio sobre o médico e suas valises tecnológicas: contribuições para compreender as reestruturações produtivas do setor Saúde. Interface (Botucatu). 2000; 4(6):109-16.

19. Campos GWS. Um método para análise e co-gestão de coletivos: a constituição do sujeito, a produção de valor de uso e a democracia das instituições: o método da roda. São Paulo: Hucitec; 2000.

20. Carvalho MS, Sousa MF. Como o Brasil tem enfrentado o tema provimento de médicos? Interface (Botucatu). 2013; 17(47):913-26.

21. Foucault M. O cuidado com a verdade. In: Foucault M. Ditos \& Escritos V: Ética, sexualidade, política. Rio de Janeiro: Forense Universitária; 2010.

22. Tribunal de Contas da União. Relatório de Auditoria. TC n. 005.391/2014 8. Ata n. 7/2015, de 4 de março de 2015. Brasília: Plenário TCU; 4 Mar 2015.

23. Brasil. Portaria Interministerial n. 2.087, de $1^{\circ}$ de setembro de 2011. Institui o Programa de Valorização do Profissional da Atenção Básica. Brasília: Diário Oficial da União; 1 Sep 2011.

24. Brasil. Portaria MS n. 1.377, de 13 de Junho de 2011. Estabelece critérios para definição das áreas e regiões prioritárias com carência e dificuldade de retenção de médico integrante de equipe de saúde da família oficialmente cadastrada e das especialidades médicas prioritárias de que tratam o inciso II e o $\S 3^{\circ}$ do art. $6^{\circ}$-B da Lei n. 10.260 , de 12 de julho de 2001 , no âmbito do Fundo de Financiamento Estudantil (FIES) e dá outras providências (Redação dada pela PRT GM/MS n. 203 de 08.02.2013). Brasília: Diário Oficial da União; 13 Jun 2011

25. Brasil. Portaria MS n. 203, de 8 de fevereiro de 2013. Altera a Portaria n. $1.377 / \mathrm{GM} / \mathrm{MS}$, de 13 de junho de 2011, que estabelece critérios para definição das áreas e regiões prioritárias com carência e dificuldade de retenção de 
médico integrante de equipe de saúde da família oficialmente cadastrada e das especialidades médicas prioritárias de que tratam o inciso II e o $\S 3^{\circ}$ do art. $6^{\circ}$-B da Lei n. 10.260 , de 12 de julho de 2001, no âmbito do Fundo de Financiamento Estudantil (FIES) e dá outras providências. Brasília: Diário Oficial da União; 8 Feb 2013.

26. Brasil. Portaria Conjunta SGTES/MS n. 1, de 21 de janeiro de 2014. Dispõe sobre o Módulo de Acolhimento e Avaliação de médicos intercambistas nas ações educacionais e de aperfeiçoamento desenvolvidas no âmbito do Projeto Mais Médicos para o Brasil. Brasília: Diário Oficial da União; 21 Jan 2014.
27. Brasil. Portaria Conjunta SGTES/MS-SESU/MEC n. 31, de 5 de junho de 2015. Dispõe sobre o Módulo de Acolhimento e Avaliação do Projeto Mais Médicos para o Brasil. Brasília: Diário Oficial da União; 5 Jun 2015.

28. Conselho Federal de Medicina. Radiografia do ensino médico. Boletim online. Brasília: CFM; 2015.

29. Weber CAT. Programa de Saúde da Família: educação e controle da população. Porto Alegre: AGE; 2006.

30. Weber CAT. Programa de saúde da família e o governamento das populações. Educação \& Realidade. 2011; 36(3):867-82. 